\title{
Cloning and Characterization of a Candidate Auxin Plant Growth Regulator-Activated Cell Surface Hydroquinone (NADH) Oxidase
}

\author{
Laura M. C. Ades, Dorothy M. Morré, D. James Morré* \\ Mor-NuCo, Inc., Purdue Research Park, West Lafayette, USA \\ Email: ${ }^{*}$ dj_morre@yahoo.com
}

Received 7 October 2014; revised 20 November 2014; accepted 9 December 2014

Copyright (C) 2014 by authors and Scientific Research Publishing Inc.

This work is licensed under the Creative Commons Attribution International License (CC BY). http://creativecommons.org/licenses/by/4.0/

(c) (†) Open Access

\begin{abstract}
ENOX (ECTO-NOX) proteins of the external surface of the plasma membrane catalyze oxidation of both NADH and hydroquinones and protein disulfide-thiol interchange. They exhibit both prionlike and time-keeping (clock) properties. The oxidative and interchange activities alternate to generate a regular period of $24 \mathrm{~min}$ in length. Here we report the cloning, expression and characterization of a constitutive plant ENOX protein activated by both natural (Indole-3-acetic acid, IAA) and synthetic (2,4-dichlorophenoxyacetic acid, 2,4-D) auxin plant growth regulators with an optimum of about $1 \mu \mathrm{M}$, higher concentrations being less effective. The gene encoding the 213 amino acid protein (ABP20) is found in EMBL accession number U81162. Functional motifs characteristic of ENOX1 proteins, previously identified by site-directed mutagenesis, are present in the candidate auxin-activated ENOX (dNOX, ENOX5), including adenine nucleotide and copper binding motifs along with essential cysteines and a motif having homology with a previously identified auxinbinding motif. Periodicity was exhibited by both the oxidative and protein disulfide-thiol interchange activities as is characteristic for other ENOX proteins. Activity was blocked by the ENOX2specific quassinoid inhibitor glaucarubolone and other ENOX2 inhibitors but not by the ENOX1specific quassinoid inhibitor simalikalactone $D$. Activity required both auxin and bound copper. The inactive auxin 2,3-D was without effects.
\end{abstract}

\section{Keywords}

Auxin, Auxin-Binding Protein, 2,4-D, dNOX, ENOX5: ECTO-NOX Proteins

\footnotetext{
${ }^{*}$ Corresponding author.
} 


\section{Introduction}

During the past ten decades of auxin biology, a diverse network of auxin responsive proteins has emerged: receptors, transporters, synthesizers, inactivators, etc. [1]. In this report, yet another role for an auxin responsive protein is evidenced, that of a growth related cell surface hydroquinone oxidase. One or more hormone-responsive external plasma membrane hydroquinone oxidases capable of catalyzing protein disulfide interchange and that oxidize $\mathrm{NAD}(\mathrm{P}) \mathrm{H}$ as an alternate substrate $($ External NADH oxidase $=\mathrm{ENOX})$ have been demonstrated for all animal and plant species thus far investigated as well as for yeasts [2] [3]. Based on activity characteristics, three related ENOX proteins have emerged. One (CNOX or ENOX1) is both constitutive and widely distributed [4]. A second ENOX activity designated tNOX or ENOX2 is tumor or cancer-associated [5] [6]. A third protein with ENOX-like activity (designated arNOX) is age-related [7] and evident only in aged individuals, late passage cultured cells or senescent short-lived plant parts.

The ENOX1 and ENOX2 proteins function in the enlargement phase of cell growth [8]-[10]. When their activity is inhibited, cells are unable to enlarge [11]-[14]. As plant cell enlargement has traditionally been considered to be dependent upon the presence of small molecular regulators known as auxins [15], it was natural to seek evidence for an ENOX protein stimulated or activated by auxins. Observations of an auxin-stimulated NADH oxidase activity of the external surface of the plasma membrane of plants were reported early [16]-[18] in response to either natural or synthetic auxin regulators. Both the structural requirements for activity and the dose dependency of the auxin-stimulated ENOX paralleled those of auxin-stimulated elongation of excised dark grown stem segments (see Morré and Morré [3] for a summary of these observations).

Studies with purified plasma membranes and with protein fractions solubilized from plasma membranes [19] together with auxinometer measurements of cell elongation measured at intervals of 3 min following auxin addition [10] indicated that the constitutive, auxin-unresponsive cell surface NADH oxidase and the auxin-stimulated activity were distinct proteins and that the auxin-stimulated activity was specifically induced in response to added auxin.

In a previous report [20], purification of a protease-resistant protein fragment with drug-resistant ENOX1 activity and a period length of 24 min from human serum protein was described. The protein fragment was blocked to direct sequencing and was resistant to further protease digestion. Polyclonal antibodies raised to the fragment blocked auxin-responsive NADH oxidase and auxin binding of plant plasma membrane vesicles but failed to yield immunoreactive clones upon expression cloning. Subsequent cloning of ENOX1 proteins first from yeast [21] and then from Arabidopsis [22] provided sequence information to identify potential functional motifs. These motifs, when located in a single polypeptide chain together with that of a known auxin-binding motif, resulted in the identification of a candidate 213 amino acid sequence ABP-20 from Prunus persicaria [23] that contained an auxin binding motif with homology to the auxin binding site of ABP1 [24] but of different specificity (2,4-D > PCIB > NAA = IAA). When expressed in E. coli and purified, the candidate protein exhibited all of the distinguishing characteristics of an ENOX protein but where the activity obligatorily required the addition of auxin (natural or synthetic) for activity.

Among the distinguishing characteristics of ENOX proteins that permit their unequivocal identification is that the proteins exhibit two activities that alternate [2] [14]. The first activity is that of a hydroquinone oxidase (NADH serves as an alternate substrate for this activity) [25]. The second is that of a protein disulfide-thiol interchange measured either from the restoration of activity to inactive (scrambled) RNase [26] or from the cleavage of dithiodipyridine substrates [27]. Each activity generates a distinct oscillatory activity with a period length of 24 min for ENOX1. The strictly periodic activity of the ENOX proteins along with a subcellular location at the external surface of the plasma membrane distinguishes their activity from all other oxidase or protein disulfide isomerase forms [6] of both plant and animal cells. In this report, candidate auxin-activated plant ENOX protein designated dNOX (for 2,4-D-stimulated NOX, ENOX5) was expressed in bacteria and characterized as having functional motifs consistent with this activity model.

\section{Methods}

\subsection{Search for Candidate Auxin-Activated NOX from Plants}

The library of known auxin binding proteins was searched for adenine nucleotide binding sites (GXGXXG), potential protein disulfide interchange sites $(\mathrm{CKX})$, and copper binding sites $[\mathrm{H}(\mathrm{Y}) \mathrm{XH}(\mathrm{Y})]$. One such protein 
ABP-20 from Prunus persicaria [23] that contained the appropriate sequence motifs G59LGIAG, C44KK, H106TH and L150LH along with the auxin binding motif H106THP109GASEVLIVAQ with homology to the auxin binding site of ABP1 [24] was identified and selected for evaluation as a candidate for the auxin-stimulated ENOX1 (dNOX) from plants (Figure 1).

\title{
2.2. Plasmids Construction
}

Plasmids carrying the open reading frame (M1 to N209 of ABP-20 (Prunus persicaria)) sequence were prepared by inserting the $\mathrm{pET} 11 \mathrm{~b}$ vector (between NheI and BamHI sites) within the P. persicaria sequence. The DNA sequence was synthesized by GenScript USA Inc. (Piscataway, NJ). DNA sequences of the ligation products (pET11b-ABP-20) were confirmed by DNA sequencing.

\subsection{Expression of Recombinant $P$. persicaria ENOX1}

The pET11b-ABP-20 was transformed to BL21 (DE3) competent cells. A single colony was picked and inoculated into the $5 \mathrm{ml} \mathrm{LB}+$ ampicillin (LB/AMP) medium. The overnight culture $(1 \mathrm{ml})$ was diluted into $100 \mathrm{ml}$ LB/AMP media (1:100 dilution). The cells were grown with vigorous shaking $(250 \mathrm{rpm})$ at $37^{\circ} \mathrm{C}$ to an $\mathrm{OD}_{600}$ of 0.4 - 0.6 and IPTG $(0.5 \mathrm{mM})$ was added for induction. Cultures were collected after $16 \mathrm{~h}$ incubation with shaking $(250 \mathrm{rpm})$ at $37^{\circ} \mathrm{C}$.

Cells were centrifuged at 5,000 g for $6 \mathrm{~min}$. Pellets were then resuspended in $20 \mathrm{mM}$ Tris- $\mathrm{HCl}, \mathrm{pH} 8.0$, containing $0.5 \mathrm{mM}$ PMSF, $1 \mathrm{mM}$ benzamidine and $1 \mathrm{mM}$ 6-aminocaproic and lysed by three passages through a French pressure cell (SLM Aminco) at 20,000 psi. Expression of the recombinant ABP-20 of about $20 \mathrm{kDa}$ was confirmed by SDS-PAGE with silver staining (Figure 2). Transformed cells were stored at $-80^{\circ} \mathrm{C}$ in a standard glycerol stock solution. The recombinant proteins were further purified on Criterion IEF gels (Bio-Rad, Hercules, CA). The IEF gel was cut into seven equal segments. The $\mathrm{pH}$ represented by each slice was based on IEF standards (Bio-Rad). The slices were soaked in $15 \mathrm{mM}$ Tris-Mes buffer, $\mathrm{pH} \mathrm{7,} \mathrm{at} 4^{\circ} \mathrm{C}$ for overnight with shaking. The gel-free extracts were assayed for ENOX activities.

\subsection{Protein Determination}

Protein concentrations were determined by the bicinchoninic acid (BCA) method [28] (BCA Protein Assay Kit, Thermo Scientific, Rockford, IL, USA) with bovine serum albumin as the standard.

\subsection{Enzyme Activity Assays}

Oxidation of NADH was determined spectrophotometrically from the disappearance of NADH measured at 340 $\mathrm{nm}$ in a reaction mixture containing $25 \mathrm{mM}$ Tris-MES (pH 7.2), $100 \mu \mathrm{M}$ GSH, $1 \mathrm{mM} \mathrm{KCN}$ to inhibit mitochondrial oxidase activity, $150 \mu \mathrm{M} \mathrm{NADH}$ and the enzyme at $37^{\circ} \mathrm{C}$ with temperature control $\left( \pm 0.5^{\circ} \mathrm{C}\right)$ and stirring. Prior to assay, $1 \mu \mathrm{M}$ reduced glutathione was added to reduce the protein in the presence of substrate. After 10 $\min , 0.03 \%$ hydrogen peroxide was added to reoxidize the protein under renaturing conditions and in the presence of substrate to start the reaction. Activities were measured using paired Hitachi U3210 or paired SLM Aminco 2000 spectrophotometers both with continuous recording. Assays were run for $1 \mathrm{~min}$ and were repeated

\author{
1 MPQATHIFPI LFTFFLLLSS SNAAVQDFẸV ADLAAPEGPAGFSCKKPASV \\ 51 KVNDFVFSGGIAGNTSNIT KAAVTPAFVA QFPGVNGLGI SIARLDLAVG \\ 101 GVVPFHTH PGASEVLIVAQG TICAGFVASD NTFPYLQTLEK GDIMVFPQGL \\ 150 LLHFQVNGGEA PALAFASFGS ASPGLQILDF ALFKNDLPTE VIAQTTEFLDA \\ 201 AQIKKLKGVL GGTN
}

Figure 1. Sequence of the recombinant auxin-activated ENOX protein (ABP-20) consistent with the known ABP-20 sequence [22]. Cysteine $\mathrm{C} 44$ potentially involved in protein disulfide-thiol interchange and the NADH binding motif G59LGIAG are underlined. Copper sites H106TH and L150LH and the auxin binding site H106THPGASEVLIVAQ are indicated by dotted underlines. 


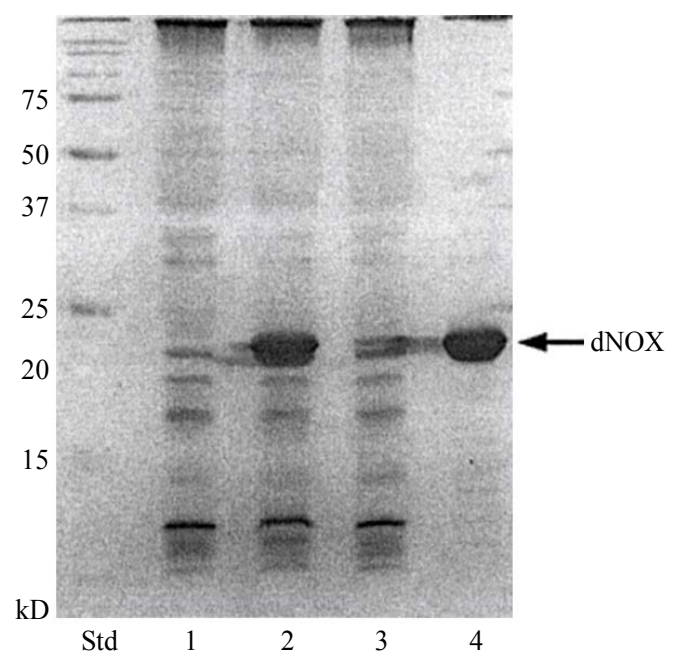

\begin{abstract}
Figure 2. Expression of $20 \mathrm{kD}$ recombinant ABP-20 shown on $14 \%$ SDS-PAGE with silver staining. Lane 1: whole $E$. coli cells carrying the vector pET11b. Lanes 2 - 4: pET11b-ABP-20 transformed E. coli. Lane 2: French press homogenate. Lane 3: French press supernatant. Lane 4: French press pellet. The expressed recombinant ABP-20 was found in the pellet of the French pressed E. coli.
\end{abstract}

on the same sample at intervals of $1.5 \mathrm{~min}$ for the times indicated. An extinction coefficient of $6.22 \mathrm{~cm}^{-1} \cdot \mathrm{mM}^{-1}$ was used to determine specific activity.

Oxidation of reduced coenzyme $\mathrm{Q}_{10}\left(\mathrm{CoQ}_{10} \mathrm{H}_{2}\right)$ was measured as the disappearance of $\mathrm{CoQ}_{10} \mathrm{H}_{2}$ at both 290 $\mathrm{nM}$ and $410 \mathrm{nM}$ [25]. The reaction was started with the addition of $40 \mu \mathrm{l}$ of $5 \mathrm{mM} \mathrm{Q}_{10} \mathrm{H}_{2}$ (Tischcon Corp., Westbury, NY). An extinction coefficient of $0.805 \mathrm{mM}^{-1} \cdot \mathrm{cm}^{-1}$ was used to calculate the rate of $\mathrm{Q}_{10} \mathrm{H}_{2}$ oxidation.

Protein disulfide-thiol interchange was determined spectrophotometrically from the increase in absorbance at $340 \mathrm{~nm}$ resulting from the cleavage of dithiodipyridine (DTDP [27]. DTDP cleavage was buffered (50 $\mathrm{mM}$ Tris-MES, $\mathrm{pH} 7)$. The assay was preincubated ( $1 \mathrm{~h}$ at room temperature) with $0.5 \mu$ moles 2,2 '-dithiodipyridine (DTDP) in $5 \mu \mathrm{l}$ of DMSO to react with endogenous reductants present with the plasma membranes. After 10 min, a further $3.5 \mu$ moles DTDP were added in $35 \mu \mathrm{l}$ DMSO to start the reaction. The final reaction volume was $2.5 \mathrm{ml}$. The reaction was monitored from the increase in absorbance at $340 \mathrm{~nm}$. Specific activities were calculated using a millimolar absorption coefficient of 6.21 .

\title{
2.6. Removal of Copper (II)
}

IEF purified dNOX was concentrated to $0.7 \mathrm{mg} / \mathrm{ml}$ by using a Centricon concentrator (Millipore Corporation, Danvers, MA) fitted with a 10,000 nominal molecular weight limit Ultracel YM membrane. Samples (50 $\mu$ l) were combined with $1 \mu \mathrm{l}$ of trifluoroacetic acid (TFA) in the presence or absence of $15 \mu 110 \mathrm{mM}$ bathocuproine. After $2 \mathrm{~h}$ of incubation at room temperature, the samples were dialyzed (Spectra/Pro dialysis membrane, molecular weight cut-off 6000 - 8000, Spectrum Laboratories (Rancho Dominquez, CA) against 20 mM Tris-HCl, $\mathrm{pH} 8$, at $4^{\circ} \mathrm{C}$ overnight.

\subsection{Site-Directed Mutagenesis}

Amino acids indicated were replaced by alanines by site-directed mutagenesis according to Braman et al. [29]. Numbered amino acids and nucleotide positions of splice variant products refer to numbers assigned to amino acids in Figure 1.

\section{Results}

The identification of the candidate plant auxin-activated ENOX protein (dNOX, ENOX5) was based on a ho- 
mology search of known auxin-binding proteins that also contained the corresponding functional motifs of known ENOX proteins ([3], see Methods). The $20 \mathrm{kDa}$ amino acid sequence selected, ABP-20 (Figure 1), contained the required functional motifs within the $20 \mathrm{kDa}$ transcript that included a potential NADH binding site at G59LGTAG, a potential protein disulfide site located at C44KK, potential copper sites at H106TH and L150LH and the auxin binding motif H106THPGASEVLIVAQ.

Expression of the recombinant ABP-20 with a molecular weight of about $20 \mathrm{kDa}$ was confirmed by SDSPAGE with silver staining (Figure 2).

\subsection{Protein Characterization}

At no point during the purification did the recombinant protein exhibit NADH oxidase activity levels above the background rate of NADH auto-oxidation in the absence of auxin addition. Upon addition of auxin (e.g., $1 \mu \mathrm{M}$ 2,4-D) the activity was enhanced 10 to 20 fold above base line activity with an auxin-induced specific activity of $0.8 \pm 0.2 \mu \mathrm{moles} / \mathrm{min} / \mathrm{mg}$ protein with IEF-purified fractions.

For more detailed evaluations, rates averaged over 1 min every 1.5 min with recombinant plant dNOX expressed in bacteria and purified by isoelectric focusing exhibited clearly the oscillatory pattern of oxidation of exogenously supplied NADH characteristic of ENOX proteins in general (Figure 3). The repeating pattern was that of five maxima, two of which were separated by $6 \min$ (maxima (1) and (2)) and the remainder (maxima (3), (4) and (5)) separated by $4.5 \mathrm{~min}(6 \mathrm{~min}+(4 \times 4.5 \mathrm{~min})=24 \mathrm{~min})$. As is characteristic of ENOX proteins from other sources, the maxima labeled (1) and (2) were more prominent than the maxima (3), (4) and (5). Similar results were obtained when the natural auxin, indole-3-acetic acid (IAA), was substituted for the 2,4-D (Figure 4).

A characteristic of all ENOX proteins is protein disulfide-thiol interchange (protein disulfide isomerase) activity illustrated by the time-dependent cleavage of a dithiodipyridyl substrate (Figure 5). An oscillatory pattern similar to that for NADH oxidation was observed for dNOX with a period length of $24 \mathrm{~min}$. As reported previously [14], with DTDP the maxima labeled (3), (4) and (5) were more pronounced than those labeled (1) and (2) suggesting an alternation of the principal maxima of NADH oxidation and protein disulfide-thiol interchange.

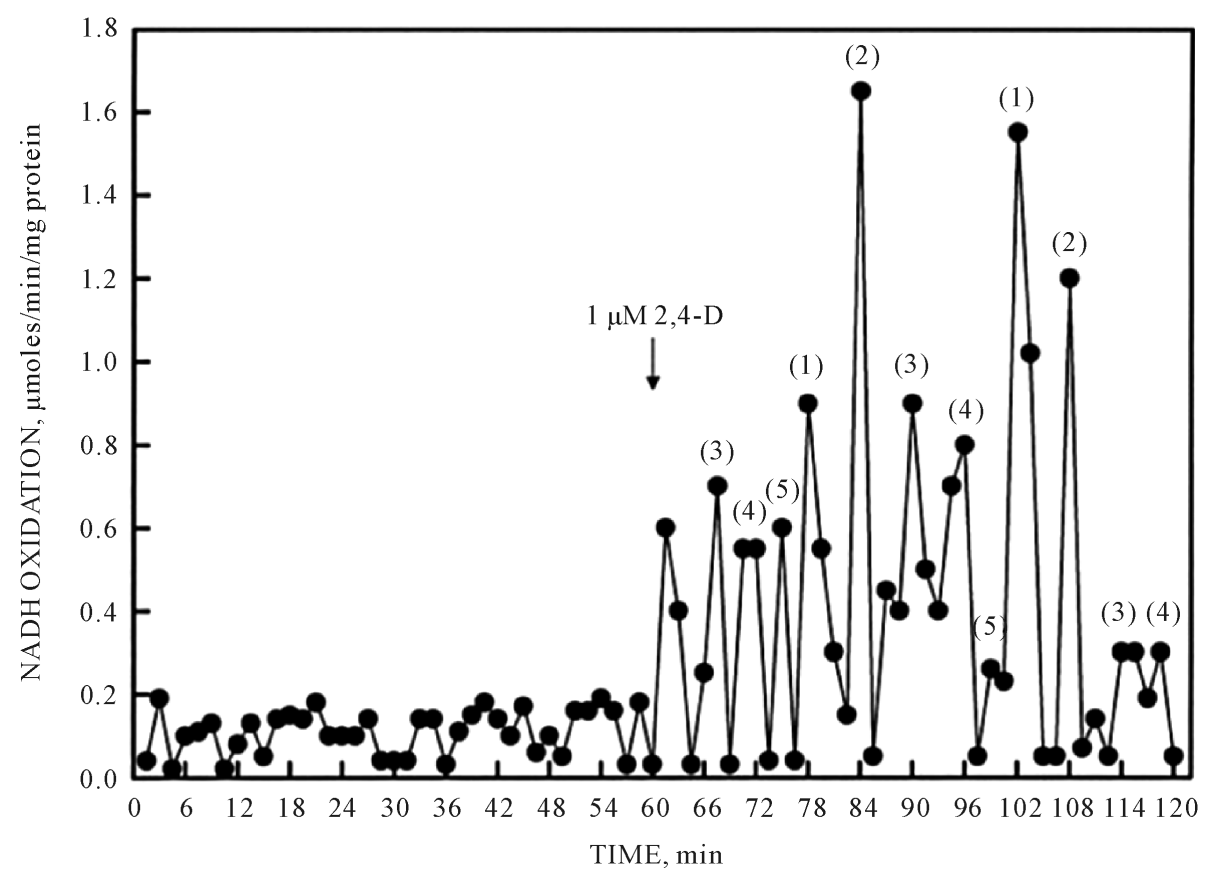

Figure 3. NADH oxidase activity of IEF purified recombinant ABP-20. 2,4-dichlorophenoxyacetic acid $(2,4-\mathrm{D})(1 \mu \mathrm{M})$ was added at $60 \mathrm{~min}$ to activate the enzyme. Illustrated is the oscillatory pattern of 5 maxima. The major maxima separated by $6 \mathrm{~min}$ are indicated by maxima labeled (1) and (2). The three minor maxima that follow (3), (4) and (5) are separated from the major maxima and each other by 4.5 min creating the $24 \min$ period $(6+(4.5$ $\times 4)=24 \mathrm{~min})$. 


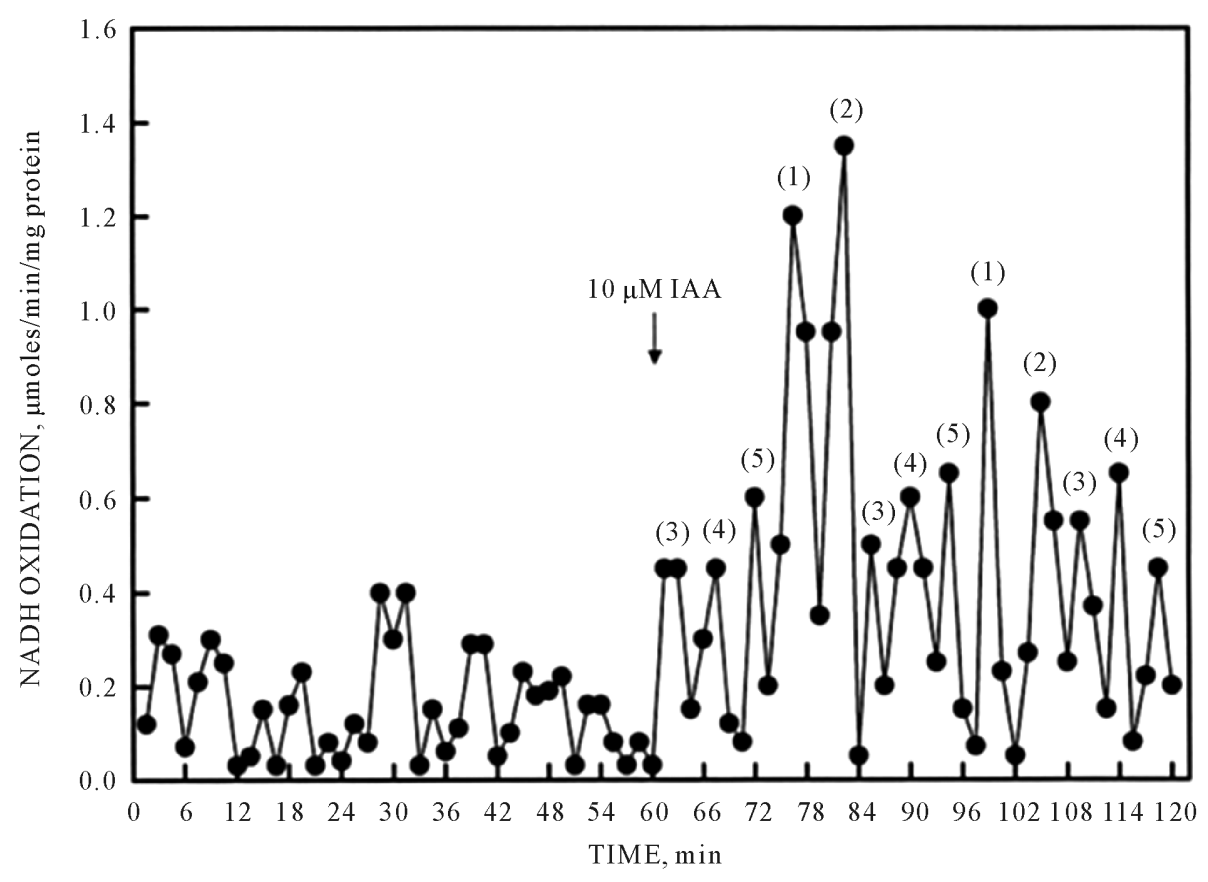

Figure 4. As in Figure 3 except activation by $10 \mu \mathrm{M}$ indole-3-acetic acid added after $60 \mathrm{~min}$.

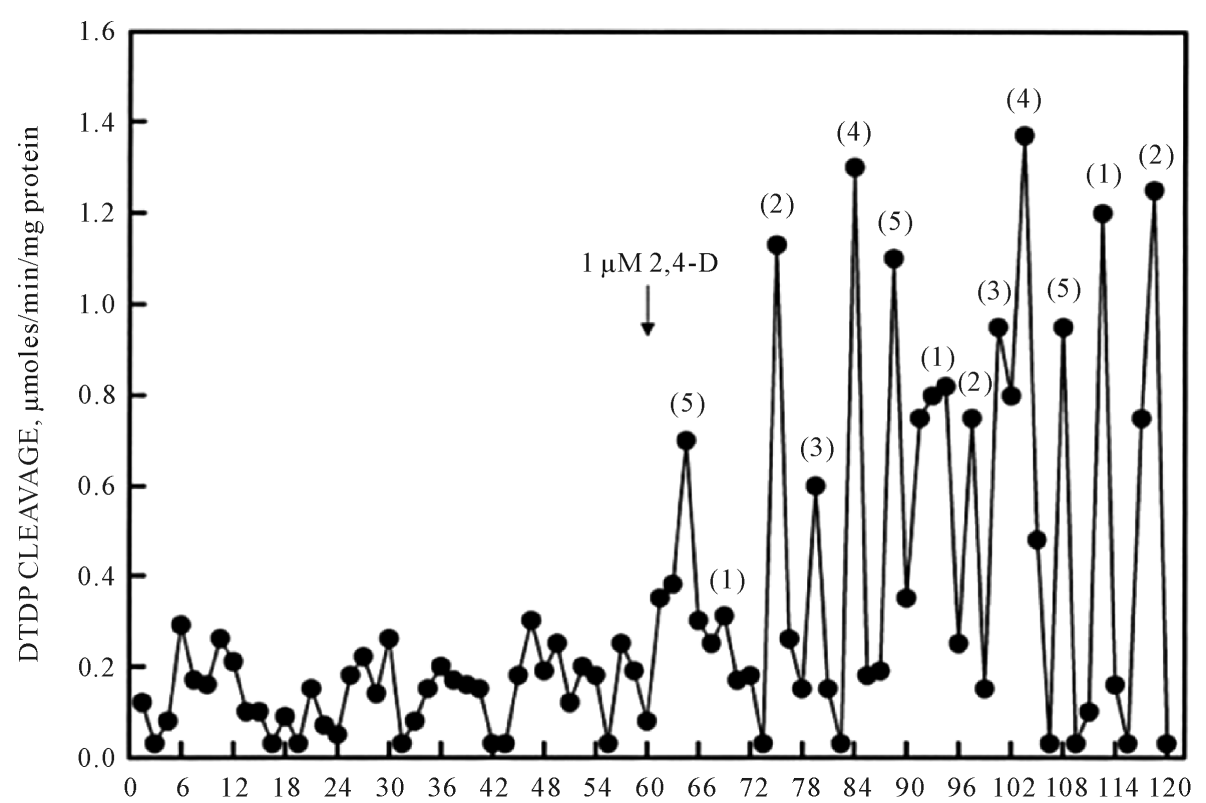

Figure 5. Protein disulfide-thiol interchange activity of IEF-purified recombinant ABP-20 measured from the cleavage of a dithiodipyridine (DTDP) substrate. 2,4-D $(1 \mu \mathrm{M})$ was added at $60 \mathrm{~min}$ to activate the enzyme. An oscillatory activity was observed with the activities were most strongly associated with the three maxima (3), (4) and (5) separated by $4.5 \mathrm{~min}$ rather than with the two maxima (1) and (2) separated by 6 min.

The recombinant ENOX1 oxidizes reduced coenzyme Q in a standard assay (Figure 6) with activity measured either at $\mathrm{A}_{410}$ (Figure 6(a)) or at $\mathrm{A}_{290}$ (Figure 6(b)). As with NADH oxidation (Figure 4), maxima labeled (1) and (2) were more pronounced than those labeled (3), (4) and (5). Hydroquinones of the plasma membrane (reduced coenzyme Q for animals/reduced coenzyme Q or phylloquinone for plants) are the physiological substrates for ENOX proteins [3]. 


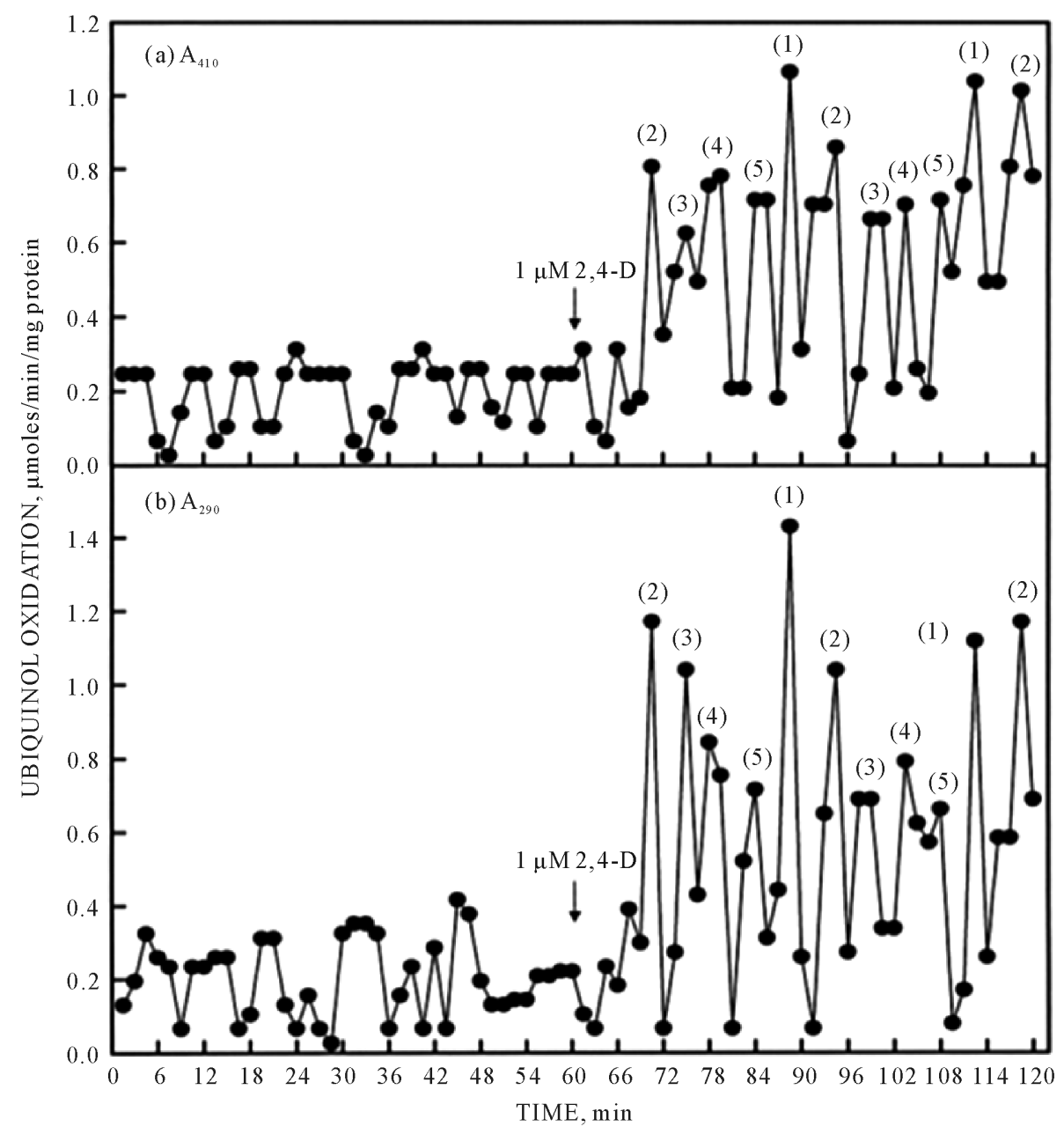

Figure 6. Ability of recombinant ABP-20 oxidize hydroquinone (reduced coenzyme Q) measured either by an increase in $\mathrm{A}_{410}$ (a) or a decrease in $\mathrm{A}_{290}$ (b). As with NADH oxidation of Figure 3, the activity oscillates with prominent maxima separated by 6 min to create a 24 min period containing 3 additional maxima separated by 4.5 min (total of 5 maxima). 2,4-D $(1 \mu \mathrm{M})$ was added at 60 min to activate the enzyme.

Primarily through reduction of the aggregation of the recombinant proteins, further purification by isoelectric focusing was required to achieve the reported specific activities. Highest specific activities were achieved at a focusing $\mathrm{pH}$ of about 5.0 which approximates the calculated isoelectric point of the recombinant protein of $\mathrm{pH}$ 5.19 .

Activity was inhibited by the thiol reagents PCMB and PCMS (Table 1). The inactive auxin analog 2,3dichlorophenoxyacetic acid (2,3-D) was without effect (Table 1) as was the ENOX1-specific quassinoid inhibitor simalikalactone D. The anticancer drugs cis platinum, doxorubicin (Adriamycin) and glaucarubolone, which specifically inhibit auxin-induced growth in plants [2] [30] also inhibited the activity of the recombinant protein. The growth inactive transplatinum was without effect (Table 1).

\subsection{ENOX1 Activity Requires the Presence of Copper}

Copper was necessary for dNOX activity (Figure 7). The IEF-purified dNOX, when unfolded in the presence of trifluoroacetic acid, retained activity after dialysis and at physiological pH (Figure 7(a)). However, if the dNOX was unfolded in the presence of the copper chelator bathocuproine, activity was lost (Figure 7(b)). Activity was subsequently restored by dialysis to remove the bathocuproine and refolding in the presence of copper at physiological pH (Figure 7(c)). 
Table 1. Auxin-stimulated NADH oxidase activity of IEF-purified recombinant ABP-20 and response to auxins and ENOX inhibitors. Averages of 3 determinations \pm standard deviations.

\begin{tabular}{ccc}
\hline Addition & Concentration & $\mu$ moles $/ \mathrm{min} / \mathrm{mg}$ \\
\hline None & & \\
2,4-dichlorophenoxyacetic acid (2,4-D) & $1 \mu \mathrm{M}$ & $0.8 \pm 0.2$ \\
2,3-dichlorophenoxyacetic acid (2,3-D) & $100 \mu \mathrm{M}$ & $0.4 \pm 0.1^{*}$ \\
Indole-3-acetic acid (IAA) & $1 \mu \mathrm{M}$ & $0.15 \pm 0.01^{* *}$ \\
2,4-D $(1 \mu \mathrm{M})+$ PCMB & $1 \mu \mathrm{M}$ & $0.8 \pm 0.05$ \\
2,4-D $(1 \mu \mathrm{M})+$ PCMS & $100 \mu \mathrm{M}$ & $0.1 \pm 0.05^{* *}$ \\
2,4-D $(1 \mu \mathrm{M})+$ Cis-platinum & $100 \mu \mathrm{M}$ & $0.3 \pm 0.2^{*}$ \\
2,4-D $(1 \mu \mathrm{M})+$ Trans-platinum & $1 \mu \mathrm{M}$ & $0.2 \pm 0.05^{* *}$ \\
2,4-D $(1 \mu \mathrm{M})+$ Doxorubicin (Adriamycin) & $1 \mu \mathrm{M}$ & $0.7 \pm 0.1$ \\
2,4-D $(1 \mu \mathrm{M})+$ Simalikalactone $\mathrm{D}$ & $1 \mu \mathrm{M}$ & $0.2 \pm 0.05^{*}$ \\
2,4-D $(1 \mu \mathrm{M})+$ Glaucarubolone & $1 \mu \mathrm{M}$ & $0.65 \pm 0.07$ \\
\hline
\end{tabular}

*Significant $(\mathrm{p}=0.037) ;{ }^{* *}$ Very significant $(\mathrm{p}=0.004-0.008)$.

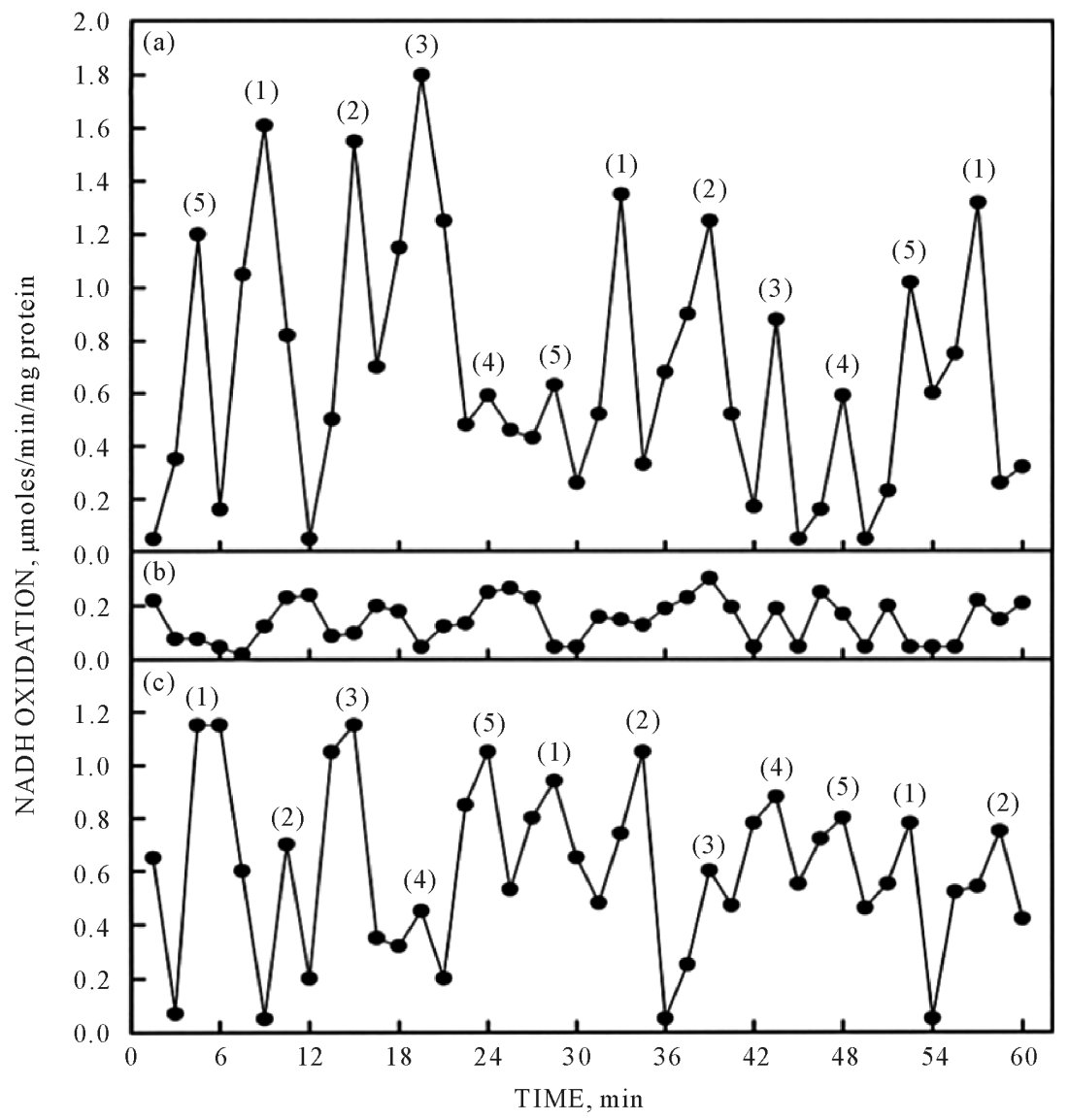

Figure 7. NADH oxidase activity of recombinant ABP-20 diminished with TFA + bathocuproine. (a) In the presence of TFA alone, the 24 min period was unaffected; (b) When assayed with TFA and bathocuproine, the 24 min period was much reduced; (c) Removal of bathocuproine by dialysis and re-addition of copper restored full activity. 2,4-D $(1 \mu \mathrm{M})$ was added from the beginning to activate the enzyme. 


\subsection{Confirmation of Functional Assignments of dNOX Motifs by Site-Directed Mutagenesis within the Structure of ABP-20}

Confirmation of functional assignments of motifs common to ENOX proteins is provided for the specific functional motifs of dNOX (ABP-20) by site directed mutagenesis (Table 2). Within the CKK motif common to ENOX1 proteins, activity was reduced by $81 \%$ in the C44A replacement for both NADH oxidation and protein disulfide-dithiol interchange activity. The G59A replacement in the putative adenine nucleotide binding motif largely eliminated both NADH oxidation and disulfide-thiol interchange. The E113A replacement in the auxin binding motif also eliminated the auxin-stimulation of NADH oxidase activity. Putative copper site replacements, H106A and H152A, reduced activities of both NADH oxidation and disulfide-thiol interchange to near background.

\section{Discussion}

The sequence of the putative plant auxin-activated ENOX protein appeared not to resemble that of ENOX proteins previously described. Except for putative functional motifs, no similarity to the human ENOX2 [6] or ENOX1 [4], the plant ENOX1 [22] or the yeast ENOX1 [21] was found. A putative NADH-binding site, a disulfide-thiol interchange site, and copper-binding sites of ENOX2 are conserved in the human ENOX1 and ENOX2 proteins while the putative anti-cancer drug binding site of ENOX2 is not.

When expressed in bacteria, the plant auxin-activated ENOX1 exhibited activity characteristics similar to those of ENOX1 proteins from mammalian [4] [20] [31] or other plant [18] [30] [32] sources. Activity measured either as NADH oxidation (artificial substrate) or oxidation of reduced coenzyme Q (native substrate) oscillated with 5 activity maxima within each 24 min period. Period length was determined from two major activity maxima separated by 6 min and indicated by as (1) and (2) in the figures. Other maxima were separated from each other and from the two major activity maxima by intervals of $4.5 \mathrm{~min}(6 \mathrm{~min}+(4 \mathrm{~min} \times 4.5 \mathrm{~min})=24 \mathrm{~min})$.

Thus far, proteins from a number of plant sources have been purified to homogeneity but have failed to yield $\mathrm{N}$-terminal amino acid sequence due to being blocked to N-terminal sequencing and being resistant to proteolytic degradation including resistance to proteinase $\mathrm{K}$. The aggregated preparations lack enzymatic activity and are refractory to resolubilization. However, ENOX proteins prepared by isoelectric focusing or eluted from isoelectric focusing gels do not aggregate, retain enzymatic activity and are stable in solution for several weeks or months when stored frozen or at $4^{\circ} \mathrm{C}$.

The marked susceptibility to inhibition by thiol reagents of both 2,4-D-induced growth and the 2,4-D-induced $\mathrm{NADH}$ oxidase activities of soybean plasma membrane suggested initially an involvement of essential active site thiols of the oxidase in the auxin growth mechanism. A similar thiol dependency was seen here with the auxin-activated NADH oxidase activity. Activity at the external surface was demonstrated using plasma membranes of right side-out orientation prepared by aqueous two-phase partition and using intact soybean cells grown in culture [33].

The NADH oxidase activity of soybean plasma membranes was subsequently shown to be stimulated by a variety of active auxins but not by their inactive counterparts [30]. Also, the responses of the plasma membrane NADH oxidase to auxins paralleled those of cell elongation including a log linear dose response to an optimum

Table 2. Confirmation of functional motifs of dNOX (ABP-20) by site-directed mutagenesis. Averages pf 3 determinations \pm standard deviations ${ }^{\mathrm{a}}$.

\begin{tabular}{ccc}
\hline \multirow{2}{*}{ Modification } & \multicolumn{2}{c}{ Auxin-Stimulated Activity, $\mu$ moles $/ \mathrm{min} / \mathrm{mg}$ protein } \\
\cline { 2 - 3 } None (wild type) & NADH Oxidation & DTDP Interchange \\
C44A & $0.8 \pm 0.1$ & $0.9 \pm 0.05$ \\
G59A & $0.15 \pm 0.05$ & $0.02 \pm 0.01$ \\
E113A & $0.06 \pm 0.02$ & $0.07 \pm 0.02$ \\
H106A & $0.03 \pm 0.01$ & $0.04 \pm 0.02$ \\
H152A & $0.04 \pm 0.01$ & $0.02 \pm 0.01$ \\
\hline
\end{tabular}

${ }^{\mathrm{a}}$ Differences from wild type are highly significant $(\mathrm{p}=0.001-0.0006)$. 
at about $1 \mu \mathrm{M}$. However as the optimum auxin concentration was exceeded, the rates declined. A further line of evidence for the NADH oxidase being a molecular target for the auxin stimulation of plant cell elongation came from results with the anticancer drug inhibitors of auxin-induced growth [30]. Doxorubicin (Adriamycin), cisplatin but not transplatin and actinomycin D all blocked the activity of the auxin-stimulated plasma membrane NADH oxidase in parallel to effects on inhibition of auxin-induced (but not control) growth (Table 1).

The auxin-stimulated NADH oxidase was subsequently purified from plasma membranes of hypocotyls of dark-grown soybean seedlings [17]. The most striking result was that the purified protein was completely inactive in the absence of auxin and exhibited an absolute requirement for auxin for activity. However, it was not until 2003 that the auxin-responsive protein band on SDS-PAGE was correctly identified when Morré et al. [19] reported that plasma membranes of soybean contained two distinct NADH oxidase activities that oscillated with a period length of about $24 \mathrm{~min}$. One, designated dNOX, with a Mr of 14 to $17 \mathrm{kDa}$, was activated by 2,4-D. The other, a constitutive activity designated CNOX (now ENOX1), with a Mr of 20.5 to $24 \mathrm{kDa}$, was unaffected by $2,4-\mathrm{D}$.

Seedlings of $A$. thaliana and tomato treated with sub-lethal concentrations of 1 to $10 \mu \mathrm{M}$ glaucarubolone remained alive but failed to elongate for periods of two to several months [13]. Once seedlings recovered from the effects of the inhibitor, they resumed growth, flowered, and produced fruits. Treated $A$. thaliana produced viable seeds that germinated and developed into normal-appearing progeny. In contrast to glaucarubolone, which inhibited preferentially auxin-induced growth and plasma membrane ENOX, simalikalactone D, a quassinoid with a $\mathrm{C}(8), \mathrm{C}(13)$ epoxymethano bridge, inhibited the constitutive ENOX activity and growth and had little or no effect on the 2,4-D-responsive ENOX and growth. The findings demonstrate a functional role of both the constitutive and the auxin-stimulated plasma membrane ENOX activities in plant cell enlargement.

With 2,4-D-stimulated cell elongation, a new increased rate of elongation and oscillatory activity was seen within a few min after auxin addition [10]. In addition, a new complex pattern of major and minor oscillations typically was observed following 2,4-D addition.

The immediate response to 2,4-D was a double set of oscillations with one corresponding to the original set of constitutive oscillations in the absence of 2,4-D. A second set of oscillations corresponding to a new 24 min period length in response to the 2,4-D was observed as the rate of cell elongation began to accelerate following the addition of 2,4-D. A new steady-state rate of elongation was achieved and a dominant single set of oscillations with a period length of $24 \mathrm{~min}$ at the 2,4-D stimulated rate was established after about $3 \mathrm{~h}$ of incubation.

The 2,4-D-stimulated activity absolutely required an active auxin such as 2,4-D or IAA for activity (Table 1) and exhibited a period length of about $24 \mathrm{~min}$ (Figures 3-6). Also, exhibiting $24 \mathrm{~min}$ oscillations was the rate of cell enlargement induced by the addition of 2,4-D or the natural auxin growth regulator, indole-3-acetic acid (IAA) [8]-[10] [13]. As discussed above, immediately following 2,4-D or IAA addition, a very complex pattern of oscillations was observed. However, after several h, a dominant 24 min period of 2,4-D-induced activity emerged at the expense of the constitutive activity [19]. The sum of the two activities remained constant. A recruitment process whereby an altered protein form converts a normal form of a protein into a likeness of itself analogous to that exhibited by prions [34] [35] was postulated to explain this unusual behavior to a growth-regulating herbicide [19].

Thus far no crystal structures have been obtained for any of the previously described ENOX proteins despite numerous attempts to do so. Success in determining a crystal structure for ABP1 [24] offers encouragement that ENOX5 might offer a similar opportunity to develop the first crystal structure for an ENOX protein.

\section{Conclusion}

The auxin-responsive cell surface hydroquinone (NADH) oxidase of plants (ENOX5) is a 213 amino acid protein (ABP-20) originally isolated from Prunus persicaria [23]. The protein lacks significant sequence homology with other auxin-responsive proteins although it is distantly related to ABP1 through auxin binding site homology. The protein has an absolute requirement for active auxins (natural or synthetic) for catalytic activity and has properties of previously characterized ENOX proteins from animals and yeast as shown by inhibitor and auxin-induced catalytic properties.

\section{Acknowledgements}

We thank Aya Ryuzoji for preparation of the figures and Peggy Runck for manuscript preparation. 


\section{References}

[1] Leyser, O. (2010) The Power of Auxins in Plants. Plant Physiology, 154, 501-505. http://dx.doi.org/10.1104/pp.110.161323

[2] Morré, D.J. (1998) NADH Oxidase: A Multifunctional Ectoproteins of the Eukaryotic Cell Surface. In: Asard, H., Bérczi, A. and Caubergs, R., Eds., Plasma Membrane Redox Systems and Their Role in Biological Stress and Disease, Kluwer Academic Publishers, Dordrecht, 121-156. http://dx.doi.org/10.1007/978-94-017-2695-5_5

[3] Morré, D.J. and Morré, D.M. (2013) ECTO-NOX Proteins. Springer, New York, 507 p. http://dx.doi.org/10.1007/978-1-4614-3958-5

[4] Jiang, Z., Gorenstein, N.M., Morré, D.M. and Morré, D.J. (2008) Molecular Cloning and Characterization of a Candidate Human Growth-Related and Time-Keeping Constitutive Cell Surface Hydroquinone (NADH) Oxidase. Biochemistry, 47, 14028-14038. http://dx.doi.org/10.1021/bi801073p

[5] Chueh, P.-J., Morré, D.J., Wilkinson, F.E., Gibson, J. and Morré, D.M. (1997) A 33.5 kDa Heat- and Protease-Resistant NADH Oxidase Inhibited by Capsaicin from Sera of Cancer Patients. Archives of Biochemistry and Biophysics, 342, 38-47. http://dx.doi.org/10.1006/abbi.1997.9992

[6] Chueh, P.-J., Kim, C., Cho, N., Morré, D.M. and Morré, D.J. (2002) Molecular Cloning and Characterization of a Tumor-Associated, Growth-Related and Time-Keeping Hydroquinone (NADH) Oxidase (NOX) of the HeLa Cell Surface. Biochemistry, 41, 3732-3741. http://dx.doi.org/10.1021/bi012041t

[7] Tang, X., Parisi, D., Spicer, B., Morré, D.M. and Morré, D.J. (2013) Molecular Cloning and Characterization of Human Age-Related NADH Oxidase (arNOX) Proteins as Members of the TM9 Superfamily of Transmembrane Proteins. Advances in Biological Chemistry, 2, 187-197. http://dx.doi.org/10.4236/abc.2013.32024

[8] Pogue, R., Morré, D.M. and Morré, D.J. (2000) CHO Cell Enlargement Oscillates with a Temperature-Compensated Period of 24 Minutes. Biochimica et Biophysica Acta, 1498, 44-51. http://dx.doi.org/10.1016/S0167-4889(00)00076-8

[9] Morré, D.J., Pogue, R. and Morré, D.M. (2001) Soybean Cell Enlargement Oscillates with a Temperature-Compensated Period Length of ca. 24 Min. In Vitro Cellular \& Developmental Biology —Plant, 37, 19-23. http://dx.doi.org/10.1007/s11627-001-0004-3

[10] Morré, D.J., Ternes, P. and Morré, D.M. (2002) Cell Enlargement of Plant Tissue Explants Oscillates with a Temperature-Compensated Period Length of ca. 24 Min. In Vitro Cellular \& Developmental Biology_Plant, 38, 18-28. http://dx.doi.org/10.1079/IVP2001249

[11] Morré, D.J., Brightman, A.O., Hidalgo, A. and Navas, P. (1995) Selective Inhibition of Auxin-Stimulated NADH Oxidase Activity and Elongation Growth of Soybean Hypocotyls by Thiol Reagents. Plant Physiology, 107, 1285-1291.

[12] Morré, D.J., Chueh, P.J. and Morré, D.M. (1995) Capsaicin Inhibits Preferentially the NADH Oxidase and Growth of Transformed Cells in Culture. Proceedings of the National Academy of Sciences of the United States of America, 92, 1831-1835. http://dx.doi.org/10.1073/pnas.92.6.1831

[13] Morré, D.J. and Greico, P.A. (1999) Glaucarubolone and Simalikalactone D, Respectively, Preferentially Inhibit Auxin-Induced and Constitutive Components of Plant Cell Enlargement and the Plasma Membrane NADH Oxidase. International Journal of Plant Sciences, 160, 291-297. http://dx.doi.org/10.1086/314133

[14] Morré, D.J. and Morré, D.M. (2003) Cell Surface NADH Oxidases (ECTO-NOX Proteins) with Roles in Cancer, Cellular Time-Keeping, Growth, Aging and Neurodegenerative Disease. Free Radical Research, 37, 795-808. http://dx.doi.org/10.1080/1071576031000083107

[15] Davies, P.J. (1995) Plant Hormones. Kluwer Academic, Dordrecht. http://dx.doi.org/10.1007/978-94-011-0473-9

[16] Morré, D.J., Navas, P., Penel, C. and Castillo, F.J. (1986) Auxin-Stimulated NADH Oxidase (Semidehydroascorbate Reductase) of Soybean Plasma Membrane: Role in Acidification of Cytoplasm? Protoplasma, 133, 195-197. http://dx.doi.org/10.1007/BF01304635

[17] Brightman, A.O., Barr, R., Crane, F.L. and Morré, D.J. (1988) Auxin-Stimulated NADH Oxidase Purified from Plasma Membrane of Soybean. Plant Physiology, 86, 1264-1269. http://dx.doi.org/10.1104/pp.86.4.1264

[18] Morré, D.J. and Brightman, A.O. (1991) NADH Oxidase of Plasma Membranes. Journal of Bioenergetics and Biomembranes, 23, 469-489. http://dx.doi.org/10.1007/BF00771015

[19] Morré, D.J., Morré, D.M. and Ternes, P. (2003) Auxin-Activated NADH Oxidase Activity of Soybean Plasma Membranes Is Distinct from the Constitutive Plasma Membrane NADH Oxidase and Exhibits Prion-Like Properties. In Vitro Cellular \& Developmental Biology_Plant, 39, 368-376. http://dx.doi.org/10.1079/IVP2003417

[20] Sedlak, D., Morré, D.M. and Morré, D.J. (2001) A Drug-Unresponsive and Protease-Resistant CNOX Protein from Human Sera. Archives of Biochemistry and Biophysics, 386, 106-116. http://dx.doi.org/10.1006/abbi.2000.2180

[21] Dick, S.S., Ryuzoji, A., Morré, D.M. and Morré, D.J. (2013) Identification of the Constitutive Ultradian Oscillator of the Circadian Clock (ENOX1) in Saccharomyces cerevisiae. Advances in Biological Chemistry, 3, 320-328. 
http://dx.doi.org/10.4236/abc.2013.33036

[22] Tang, X., Ades, L.M.C., Morré, D.M. and Morré, D.J. Molecular Cloning and Characterization of a Candidate Plant Growth-Related and Time-Keeping Constitutive Cell Surface Hydroquinone (NADH) Oxidase (ENOX1) from Arabidopsis lyrata. Unpublished.

[23] Ohmiya, A., Tanaka, Y., Kadowaki, K. and Hayashi, T. (1998) Cloning of Genes Encoding Auxin-Binding Proteins (ABP19/20) from Peach: Significant Peptide Sequence Similarity with Germin-Like Proteins. Plant and Cell Physiology, 39, 492-499. http://dx.doi.org/10.1093/oxfordjournals.pcp.a029396

[24] Woo, E.J., Marshall, J., Bauly, J., Chen, J.G., Venis, M., Napier, R.M. and Pickersgill, R.W. (2002) Crystal Structure of Auxin-Binding Protein 1 in Complex with Auxin. The EMBO Journal, 21, 2877-2885. http://dx.doi.org/10.1093/emboj/cdf291

[25] Kishi, T., Morré, D.M. and Morré, D.J. (1999) The Plasma Membrane NADH Oxidase of HeLa Cells Has Hydroquinone Oxidase Activity. Biochimica et Biophysica Acta, 1412, 66-77. http://dx.doi.org/10.1016/S0005-2728(99)00049-3

[26] Morré, D.J., De Cabo, R., Jacobs, E. and Morré, D.M. (1995) Auxin-Modulated Protein Disulfide-Thiol Interchange Activity from Soybean Plasma Membranes. Plant Physiology, 109, 573-578.

[27] Morré, D.J., Gomez-Rey, M.L., Schramke, C., Em, O., Lawler, J., Hobeck, J. and Morré, D.M. (1999) Use of Dipyridyl-Dithio Substrates to Measure Directly the Protein Disulfide-Thiol Interchange Activity of the Auxin-Stimulated NADH: Protein Disulfide Reductase (NADH Oxidase) of Soybean Plasma Membranes. Molecular and Cellular Biochemistry, 200, 7-13. http://dx.doi.org/10.1023/A:1006916116297

[28] Smith, P.K., Krohn, R.I., Hermanson, G.T., Mailia, A.K., Gartner, F.F., Provenzano, M.D., Fujimoto, E.K., Groeke, N.M., Olson, B.J. and Klenk, D.C. (1985) Measurement of Protein Using Bicinchoninic Acid. Analytical Biochemistry, 150, 76-85. http://dx.doi.org/10.1016/0003-2697(85)90442-7

[29] Braman, J., Papworth, C. and Greener, A. (1996) Site-Directed Mutagenesis Using Double Stranded Plasmid DNA Templates. Methods in Molecular Biology, 57, 31-44.

[30] Morré, D.J., Crane, F.L., Barr, R., Penel, C. and Wu, L.Y. (1988) Inhibition of Plasma Membrane Redox Activities and Elongation Growth of Soybean. Physiologia Plantarum, 72, 236-240. http://dx.doi.org/10.1111/j.1399-3054.1988.tb05828.x

[31] Brightman, A.O., Wang, J., Miu, R.K., Sun, I.L., Barr, R., Crane, F.L. and Morré, D.J. (1992) A Growth Factor- and Hormone-Stimulated NADH Oxidase from Rat Liver Plasma Membrane. Biochimica et Biophysica Acta, 1105, 109117. http://dx.doi.org/10.1016/0005-2736(92)90168-L

[32] Morré, D.J. and Morré, D.M. (1998) NADH Oxidase Activity of Soybean Plasma Membrane Oscillates with a Temperature Compensated Period of 24 min. The Plant Journal, 16, 279-284. http://dx.doi.org/10.1046/j.1365-313x.1998.00293.x

[33] DeHahn, T., Barr, R. and Morré, D.J. (1997) NADH Oxidase Activity Present on both the External and Internal Membrane Surfaces of Soybean Plasma Membranes. Biochimica et Biophysica Acta, 1328, 99-108. http://dx.doi.org/10.1016/S0005-2736(97)00077-1

[34] Griffith, J.S. (1964) Self-Replication and Scrapie. Nature, 215, 1043-1044.

[35] Prusiner, S.B. (1994) Biology and Genetics of Prion Diseases. Annual Review of Microbiology, 48, 3655-3686. http://dx.doi.org/10.1146/annurev.mi.48.100194.003255 


\section{Abbreviations}

ABP, auxin binding protein; arNOX, age-related NADH oxidase; CNOX, constitutive and drug-unresponsive cell surface NADH oxidase (ENOX1); Capsaicin, 8-methyl-N-vanillyl-6-noneamide; dNOX, 2,4-D (auxin)-activated cell surface NADH oxidase (ENOX5); 2,4-D, 2,4-dichlorophenoxyacetnic acid; DTDP, dithiodipyridine; ENOX, ECTO-NOX cell surface oxidases; IAA, indole-3-acetic acid; IEF, isoelectric focusing; NAA, $\alpha$-naphthaleneacetic acid; PCIB, p-chlorophenoxy isobutyric acid; PCMB, p-chloromercuribenzoic acid; PCMS, pchloromercursulfonic acid; SDS-Page, sodium dodecyl sulfate polyacrylamide gel electrophoresis; TFA, trifluoroacetic acid; tNOX, tumor (cancer)-associated and drug-(capsaicin) inhibited cell surface NADH oxidase (ENOX2).

\section{Nucleotide Sequence Data}

Nucleotide sequence data reported are available in the Third Party Annotation Section of the DOB/EMBL/ GenBank databases under the accession number TPA: BK008804. 
Scientific Research Publishing (SCIRP) is one of the largest Open Access journal publishers. It is currently publishing more than 200 open access, online, peer-reviewed journals covering a wide range of academic disciplines. SCIRP serves the worldwide academic communities and contributes to the progress and application of science with its publication.

Other selected journals from SCIRP are listed as below. Submit your manuscript to us via either submit@scirp.org or Online Submission Portal.
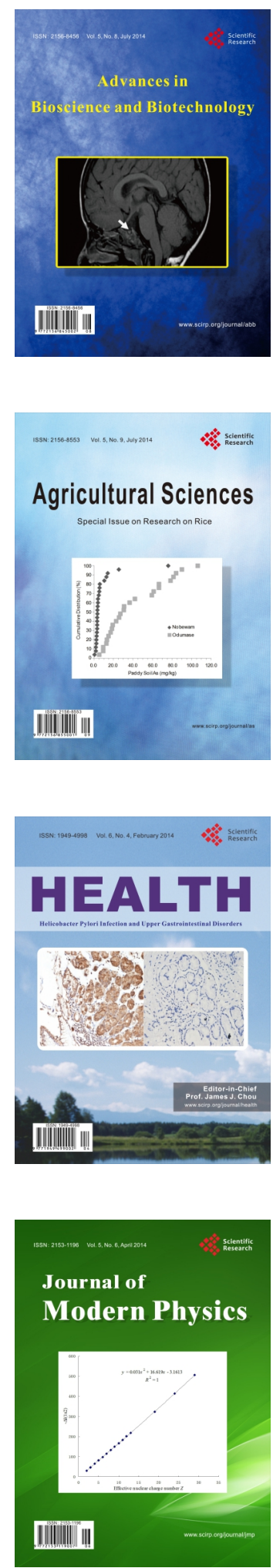
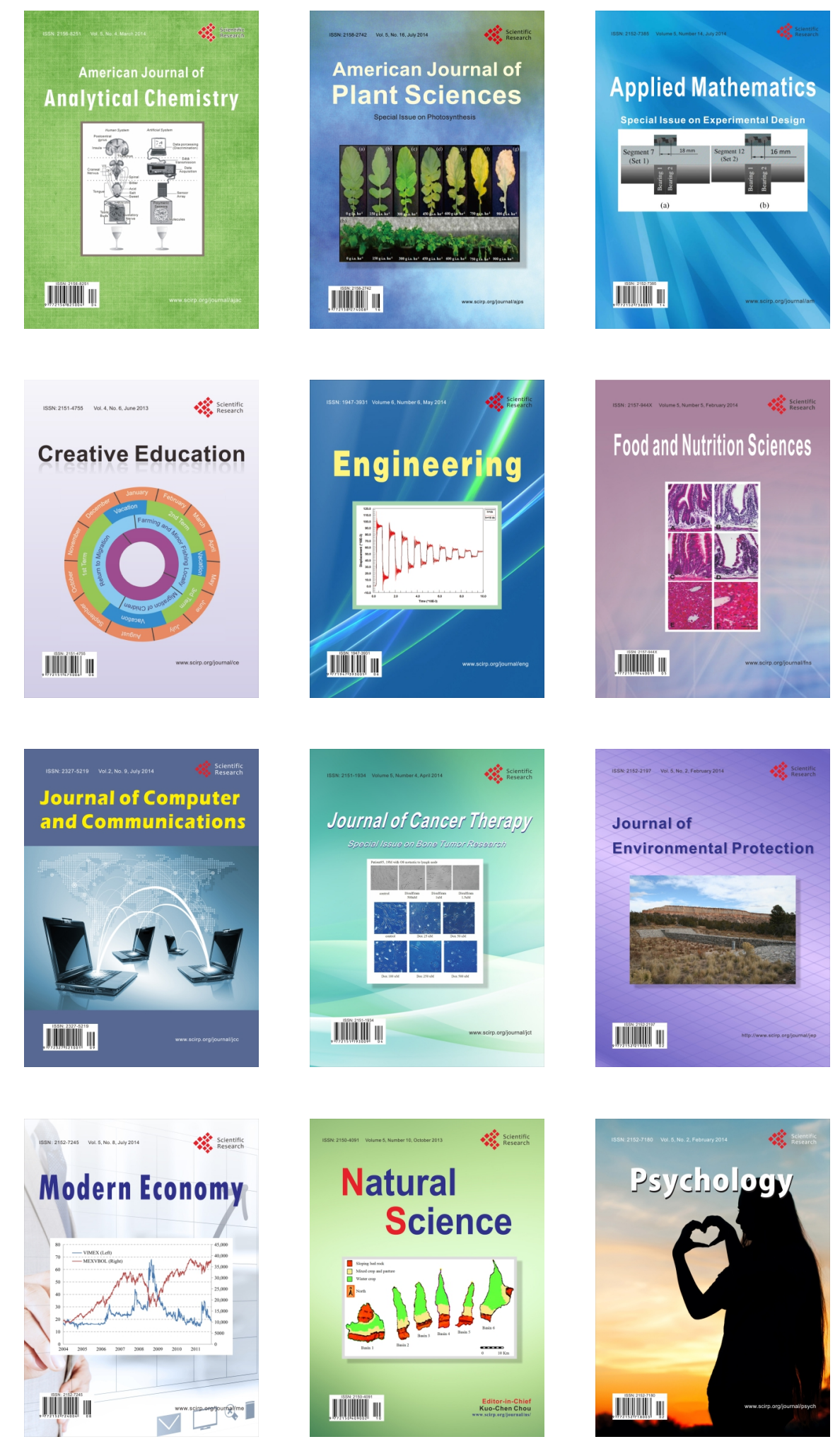